\title{
EFFECT OF SOME PLANT EXTRACTS AND PARTIAL SUBSTITUTION OF THIOVIT 80 BY PLANT EXTRACT ON POWDERY MILDEW DISEASE OF SUGAR BEET \\ EI-Fahar, Samia A. ${ }^{1}$ and Sahar M.E. Moustafa ${ }^{2}$ \\ 1. Sugar Crops Pathology Dept., Sugar Crops Institute, ARC, Egypt \\ 2. Sugar Technology Dept., Sugar Crops Institute, ARC, Egypt
}

\section{ABSTRACT}

Four experiments were conducted during 2004/2005, 2005/2006, 2006/2007 and 2007/2008 seasons at Sakha Agricultural Research Station, Kafr El-Sheikh, Egypt to study the effect of six plant extracts on controlling powdery mildew disease of sugar beet caused by Erysiphe polygoni, and its effect on different characters. Six plant extracts were used i.e. Solanum nigrum, Pancratinum maritimum, Melia azedarach, Anthemis nobilis, Ammi visnaga and Mentha piperita in different concentrations, i.e. 1000,3000 and 5000 ppm in the screen house on two sugar beet cvs. viz. Sultan and Glorious, under artificial inoculation by conidio-spores of $E$. polygoni combinations between $M$. azedarach and Thiovit 80 were used, $1 / 2 M$. azedarach $+1 / 2$ Thiovit $80,3 / 4$ M. azedarach $+1 / 4$ Thiovit 80 and $1 / 4 M$. azedarach $+3 / 4$ Thiovit 80. Those experiments were conducted in the screen house during 2004/21005 and 2005/2006. The combination was applied 3 days before and after inoculation.

Data show that $M$. azedarach at the level of 5000 ppm gave the best disease control before and after inoculation for powdery mildew followed by Ammi visnaga. Data showed also that, mixing fungicide with plant extract lead to increasing efficiency of plant extract when $1 / 4$ plant extract $+3 / 4$ Thiovit $80,1 / 2$ plant extract $+1 / 2$ Thiovit $80,3 / 4$ plant extract $+1 / 4$ Thiovit 80 , efficiency were $93.3,89.9$ and $84.5 \%$ before inoculation and $86,77.5$ and $69.9 \%$ after inoculation in comparison with the efficiency of Thiovit 80 before inoculation (94.7) and after inoculation (90.1\%) for Sultan cv. while efficiency for Glorious the date showed the same trend as 93.5, 90.2 and $84.4 \%$ before inoculation, on the other hand, it recorded $87.4,78.9$ and $70.1 \%$ after inoculation for the three combinations, respectively. While, Thiovit 80 recorded efficiency of $95.6 \%$ before inoculation and $91.2 \%$ after inoculation.

In the field experiment, $M$. azedarach $(5000 \mathrm{ppm})$ and the combination $3 / 4 \mathrm{M}$. azedarach $+1 / 4$ Thiovit 80 , was used because it has high efficiency for controlling powdery mildew disease as well as to reduce pollution and costs.

During 2006/2007, 2007/2008 seasons, disease severity (\%) was reduced to more than $50 \%$ by utilization of $3 / 4 M$. azedarach $+1 / 4$ Thiovit 80 , efficiency reached to $68.1 \%$ for Sultan and $70.1 \%$ for Glorious during 2006/2007.

Data also showed that chlorophyll content was high, 67.5 and 77.4 for Sultan and Glorious cvs. All studied characters were affected, like, root weight, TSS\%, sucrose (\%), purity and increase percentages. Increase \% in root weight 61.1 and $58.8 \%$ for Sultan and Glorious, respectively. While, increase \% in sucrose; was 62.6 and $37.6 \%$ for Sultan and Glorious, respectively.

Phenolic compounds showed negative correlation between disease severity and phenolic compounds.

AUDPC affected with disease severity (\%), when disease severity increased, AUDPC increased.

So, this research paper pointed out to the possibility of replacing fungicides by plant extracts of for disease control or of foliage diseases of sugar beet, either alone or mixed with Thiovit 80 to reduce the costs and environmental pollution as well as preventing residual effect of the fungicide on produced sugar. 


\section{INTRODUCTION}

Sugar beet powdery mildew, caused by the fungus E. plygoni now occurs in all sugar beet growing areas and can reduce sugar yield up to $30 \%$. Many crops are infected by similar appearing powdery mildews. Moreover, if the disease is not controlled it can cause a 20 to 35 percent loss in sugar yield. Crop loss is due to reduced root yield and often to a lower concentration of sugar in roots. Both effects apparently are due to a reduced efficiency of diseased leaves and to their premature death when roots are rapidly enlarging (Grimmer et al., 2007). Sugar beet leaves infected with powdery mildew show declining rates of net photosynthesis as the disease develops; relative to healthy controls, reductions of $75 \%$ after inoculation (Gordon and Duniway, 1981).

The disease is favored by a warm, dry climate, like Egypt, in addition, failure of the disease to develop on young plants in the field appears to be due to an increased susceptibility of leaves as they grow older, rather than to a microclimate effect within the foliage canopy that might be more favorable for spore germination and growth. It is common to see abundant signs of the mild on the stunted and open leaf canopy of nitrogen deficient plants (Paulus, 2008). In recent study of El-Fahar, 2008, losses in sucrose could be reached to $82.9 \%$ for some cvs. due to powdery mildew infection. Controlling powdery mildew disease is the only solution where the resistant variety is not available.

Minimizing chemical application is the main target of the environmental protective people to have an environment free from pollution and chemical hazards, and looking forward to a clean cultures for feed and food. Fungicides were used extensively for controlling most of the susceptible sugar beet cvs. sulfur (Thiovit 80 ) was applied for controlling powdery mildew (Karaoglanidis and Karadimos, 2005). Use of botanical pesticides (natural plant products) in an agroecosystem is now emerging as one of the prime means to protect crop production and environment from pesticidal pollution. There is practically no risk of developing pest resistance to these products when used in natural forms (Prakash and Rao, 1997). Plant extracts were frequently reported to be fungi toxic to various fungi (Shimon et al., 1993). So this research paper was undertaken to study the efficacy of some plant extracts as well as some combinations between the recommended fungicide and the selected plant extract on controlling powdery mildew disease. In this respect, screen house and field experiments were carried out.

\section{MATERIALS AND METHODS}

Plant materials:

\section{a. Sugar beet cultivars:}

Two sugar beet cvs. i.e. Sultan and Glorious were selected according to the previous study of El-Fahar (2008) to perform the experiment either in screen house or in the field during the course of this study.

b. Higher plants extract: 
Six higher plant samples/parts were used to test their antifungal effects on E. polygoni through preparing plant extract solutions. These plants are; Solanum nigrum (Black nightshade), Pancratinum maritimum (Soosan bulbs), Melia azedarach (Neem), Anthemis nobilis (Chamomile), Ammi visnaga (Pick tooth or Khella), and Mentha piperite (Mente).

Samples of plants shown in Table (1) were collected from different regions of Egypt and were identified by specialists. Extraction procedures were applied according to Scott and Mickibben, 1978 and Ashry et al., 1999.

The plant extractions were diluted to get a series of concentrations i.e., 1000,3000 and 5000 ppm (mg).

Table (1): Some higher plants screened for their inhibitory effect against powdery mildew disease of sugar beet.

\begin{tabular}{|c|c|c|c|c|c|c|}
\hline No. & $\begin{array}{c}\text { Scientific } \\
\text { name }\end{array}$ & $\begin{array}{c}\text { Common } \\
\text { name }\end{array}$ & $\begin{array}{c}\text { Arabic } \\
\text { name }\end{array}$ & $\begin{array}{l}\text { Part } \\
\text { used }\end{array}$ & Family & $\begin{array}{c}\text { Solvent system or } \\
\text { extractives }\end{array}$ \\
\hline 1 & $\begin{array}{c}\text { Solanum } \\
\text { nigrum }\end{array}$ & $\begin{array}{l}\text { Black night } \\
\text { shade }\end{array}$ & 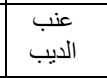 & Leaves & Solanaceae & $\begin{array}{c}\text { Methanol/acetone } \\
(1: 1) \text { water }\end{array}$ \\
\hline 2 & $\begin{array}{c}\text { Pancreatinum } \\
\text { maritimum }\end{array}$ & $\begin{array}{c}\text { Soosan } \\
\text { bulbs }\end{array}$ & بلزيم & Bulbs & Amaryllidaceae & $\begin{array}{c}\begin{array}{c}\text { Ethanol/petroleum } \\
\text { ether }\end{array} \\
\end{array}$ \\
\hline 3 & $\begin{array}{c}\text { MElia } \\
\text { azedarach }\end{array}$ & Neem & زنزلخت & Fruits & Meliaceae & $\begin{array}{c}\text { Petroleum either } \\
(40-60)\end{array}$ \\
\hline 4 & $\begin{array}{c}\text { Anthemis } \\
\text { nobilis }\end{array}$ & Chamomile & شيح & Leaves & Anacordiaceae & Acetone \\
\hline 5 & Ammi visnaga & $\begin{array}{c}\text { Khella (Pick } \\
\text { tooth) }\end{array}$ & خله & Seeds & Umbelliferaceae & Acetone \\
\hline 6 & $\begin{array}{l}\text { Mentha } \\
\text { piperita }\end{array}$ & Mente & أن أوراقع & Leaves & Myrtaceae & Volatile oil \\
\hline
\end{tabular}

\section{Extraction procedure:}

Fresh plant materials were washed, dried in an oven at $40^{\circ} \mathrm{C}$ and ground to fine powder. The dried powder of each plant material was extracted, almost to exhaustion in host extraction apparatus (Soxhlet) with the specified solvent systems, presented in Table (1). The extracts were filtered, dried over anhydrous sodium sulphate and evaporated to dryness under reduced pressure by a rotary evaporator. The residue was weighted and dissolved in acetone to give the desired concentration. Volatile oils were isolated form plant materials by stem distillation using Clevenger trap. Total alkaloids were isolated form fruits of black pepper by the method described by Scott and McKibben, 1978.

\section{Test organism}

Artificial inoculation was done by spore suspension of E. polygoni, 60 days from planting and was prepared and sprayed at a rate of $40 \times 10^{3}$ conidio-spores/ml on leaves (El-Fahar, 2008), relative humidity was kept high by using plastic sheets. Scoring and disease assessment was done according to Hills et al. (1980) scale.

3. Experimental design:

a. Screen house experiments: 


\section{El-Fahar, Samia A. and Sahar M.E. Moustafa}

Screen house experiment was conducted at Sakha Agricultural Research Station, Kafr El-Sheikh, Egypt during 2004/2005 and 2005/2006 seasons. Microplots of $2 \times 10 \mathrm{~m}^{2}$ was used. Each cultivar was grown in 3 rows of 8 plants, keeping $60 \mathrm{~cm}$ and $20 \mathrm{~cm}$ between rows and plants within row, respectively. Split split plot design with three replicates was used. Cultivars were allocated in the main plot, plant extracts were allocated in the sub plots concentrations of plant extract were allocated in sub-sub plots. Plant extracts were evaluated for their efficiency against $E$. polygoni as follow:

The six tested plant extracts were used in three concentrations i.e., 1000,3000 and 5000 ppm during 2004/2005 and 2005/2006 seasons. Plant extracts were applied 3 days before or after artificial inoculation with $E$. polygoni condio-spores. The fungicide (Thiovit 80) was applied in recommended dose ( $2.5 \mathrm{gm} /$ liter) 3 days before or after inoculation. During $2005 / 2006$ season, out of the six plant extracts, only M. azedarach was chosen with full dose (5000 ppm), 3/4, 1/2 and 1/4 dose mixed with $1 / 4,1 / 2,3 / 4$ dose of chemical fungicide (Thiovit 80 ), the score of disease severity were recoded after 90 days from sowing, 8 readings were scored with 15 days intervals.

\section{b. Field experiments:}

Two field experiments were conduced at Sakha Agricultural Research Station Farm during 2006/2007 and 2007/2008 seasons. A split plot design with three replicates was used. Main plots were devoted to cultivars (Sultan and Glorious), while sub plots were occupied by treatments (M. azedarach, M. azedarach (3/4) + Thiovit $80(1 / 4)$ and Thiovit $80(2.5 \mathrm{gm} / \mathrm{L})$. Some plots were left for natural infection by fungus without spraying.

Plot size was kept at $3 \times 7 \mathrm{~m}^{2}$, keeping $50 \mathrm{~cm}$ between rows and 20 $\mathrm{cm}$ within row. Date of sowing was adjusted on October 15 for both seasons.

All the recommended cultural practices for the experiment were applied according to the recommendation of sugar beet crop in Egypt.

Different measures and traits were measured as follow:

1.Disease severity of E. polygoni was recorded when the infection started to appear and 8 readings were recorded at 15 days intervals up to harvest. Disease assessment was done according to Hills et al. (1980) scale.

2. Efficiency \% = Diseaseseverityof control-diseaseseverityof treamtent

$$
\text { Diseaseseverityof control }
$$

3.Total soluble solids percentage: was determined in fresh roots for each cultivar using hand refractometer (McGinnis, 1982).

4.Sucrose (\%): sucrose percentage was estimated according to A.O.A.C. (1990).

5.Purity (\%): It was calculated by dividing percentage of sucrose on total soluble solids (TSS).

6. Root weigh $\mathrm{t}(\mathrm{kg} / \mathrm{plant})$, the two central ridges of each plot were estimated in Kilograms.

7. The increase $(\%)$ due to each treatment over the control $=\frac{\text { Treatment }- \text { control }}{\text { Treatment }} \times 100$.

8.Phenolic compounds: 
a. Free phenols: were determined using folin Ciocalteu reagent described by Bray and Thrope (1954).

b. Conjugated phenols:

Conjugated phenols $=$ total phenols-free phenols.

c. Total phenols: were determined in the ethanolic extract of sugar beet leaves using the method described by Snell and Snell (1953).

9. Area Under Disease Progress curve (AUDPC):

AUDPC was calculated as according to Pandy et al. (1989) as follow:

Where:

$$
\left.A U D P C=D\left[1 / 2\left(Y_{1}+Y_{k}\right)+\left(Y_{2}+Y_{3}\right) \ldots Y_{i k-1}\right)\right]
$$

$Y_{1}, Y_{2} \ldots . Y_{k}$ are the $K$ disease score at constant interval of $D$ days.

10. Chlorophyll content: Total chlorophyll content was determined in $\mathrm{mg}$ by using chlorophyll meter (SPAD-502) by taking the average of 5 readings in each record for each of the four replicates on the leaves directly.

Statistical analysis was done according to Gomez and Gomez (1983).

\section{RESULTS AND DISCUSSION}

a. Screen house:

1. Effect of certain plant extracts on powdery mildew incidence:

The effect of the six plant extracts at three concentrations, i.e. 1000, 3000 and 5000 ppm for each on disease severity of E. polygoni was studied in microplots during 2004/2005 season. The fungicide Thiovit 80 at 2.5 $\mathrm{gm} / \mathrm{liter}$ and untreated plants of Sultan and Glorious cvs. were used for comparison in this study.

Data presented in Table (2) indicated that all concentrations of the tested plant extracts significantly reduced disease severity of $E$. polygoni in comparison with the untreated plants. Application of Thiovit 80 before and after artificial inoculation with E. polygoni conidio-spores showed almost completely protection against infection with the causal pathogen.

Table (2): Effect of certain plant extracts as well as chemical fungicide against powdery mildew disease incidence on two sugar beet cvs. during 2004/2005 season (screen house).

\begin{tabular}{|c|c|c|c|c|c|c|c|c|c|c|c|c|}
\hline \multirow{3}{*}{$\begin{array}{l}\text { Plant } \\
\text { extract }\end{array}$} & \multicolumn{6}{|c|}{ Disease severity of Sultan } & \multicolumn{6}{|c|}{ Disease severity of Glorious } \\
\hline & \multicolumn{2}{|c|}{$1000 \mathrm{pm}$} & \multicolumn{2}{|c|}{3000 ppm } & \multicolumn{2}{|c|}{5000 ppm } & \multicolumn{2}{|c|}{$1000 \mathrm{pm}$} & \multicolumn{2}{|c|}{3000 ppm } & \multicolumn{2}{|c|}{5000 ppm } \\
\hline & Before & After & Before & After & Before & After & Before & After & Before & After & Before & After \\
\hline S.nigrumP. & 48.4 & 52.1 & 42.8 & 47.1 & 37.8 & 42.5 & 29.5 & 31.2 & 27.9 & 29.7 & 24.5 & 26.1 \\
\hline maritimumM & 46.5 & 53.11 & 42.4 & 50.0 & 38.4 & 46.7 & 31.9 & 32.6 & 29.5 & 31.7 & 25.3 & 26.8 \\
\hline azedarach & 27.5 & 32.7 & 22.4 & 27.2 & 14.5 & 19.8 & 21.5 & 28.3 & 16.6 & 22.5 & 8.7 & 14.5 \\
\hline obilis & 39.7 & 48.2 & 32.1 & 40.3 & 21.6 & 28 & 26 & 29.4 & 2 & 9 & 13.6 & 18.7 \\
\hline A. nisnaga & 36.5 & 42.3 & 28.4 & 35.1 & 18.6 & 24.5 & 27.2 & 27.5 & 18.9 & 24.8 & 11.4 & 19.8 \\
\hline M. piperita & 44.3 & 51.3 & 35.7 & 42.5 & 26.5 & 33.2 & 29.2 & 30.4 & 24.1 & 28.2 & 19.8 & 22.9 \\
\hline Thiovit 80 & 2.7 & 4.8 & .5 & 4.1 & 2.5 & 4.6 & 1.1 & 2.4 & 1.1 & 2.6 & 1.2 & 2.6 \\
\hline Control & 58.4 & 58.4 & 58.4 & 58.4 & 58.4 & 58.4 & 33.7 & 33.7 & 33.7 & 33.7 & 33.7 & 33.7 \\
\hline & & & & & & & & & & & & \\
\hline
\end{tabular}


From the results obtained in Table (2) spraying sugar beet plants with all the tested plant extracts at concentration of $5000 \mathrm{ppm}$ before and after inoculation with the pathogen spore suspension was more effective in reducing disease severity than the other concentrations. The highest effect on powdery mildew disease was obtained when sugar beet plants were sprayed before infection with extracts of Melia azedarach and Ammi visnaga at concentrations of $5000 \mathrm{ppm}$.

2. Complementary effect of plant extracts and Thiovit 80:

From the previous data during 2005/2006 season, the effective plant extract of $M$. azedarach (5000 ppm) was selected and mixed with Thiovit 80 as follow; (5000 ppm) M. azedarach, 3/4 M. azedarach + 1/4 Thiovit $80,1 / 2 \mathrm{M}$. azedarach $+1 / 2$ Thiovit $80,1 / 4 \mathrm{M}$. azedarach $+3 / 4$ Thiovit 80 and Thiovit $80(2.5$ $\mathrm{gm} /$ liter) were applied before and after inoculation by E. polygoni.

Data illustrated in Table (3) show that, all concentrations of the combinations between plant extract and fungicide significantly reduced disease severity of powdery mildew in comparison with the artificially inoculated plants either before or after inoculation in comparison with the plant extract alone.

The positive effect of plant extracts against powdery mildew disease reflects in turn on the root yield, whereas, it improved the yield potentiality comparable to the untreated control plants. Parameters of plant growth were enhanced due to these treatments, consequently, increasing in total soluble solids (TSS\%), sugar purity and its quantity in roots. These results are consistent with those obtained by other investigators who found an antimicrobial activity of some plant extracts against many phytopathogens (Kishore et al., 1982; Gouda, 2001 and El-Fahar, 2003).

The best combinations gave the least disease severity before and after artificial inoculation were $3 / 4 \mathrm{M}$. azedarach $+1 / 4$ Thiovit 80 followed by $1 / 2$ M. azedarach $+1 / 2$ Thiovit 80 and $1 / 4 M$. azedarach $+3 / 4$ Thiovit 80 . On the other hand, efficacy of the three combinations was very high and significantly effective in reducing powdery mildew incidence for the two tested cvs.; Sultan and Glorious in comparison with plant extract alone.

Table (3): Effect of plant extract (alone or mixed with a fungicide) on powdery mildew disease of two sugar beet cvs. during 2005/2006 season under screen house conditions.

\begin{tabular}{|c|c|c|c|c|c|c|c|c|c|}
\hline \multirow{3}{*}{$\begin{array}{l}\text { Combination plant } \\
\text { extract fungicide }\end{array}$} & \multirow{3}{*}{$\begin{array}{c}\text { Concentration } \\
\text { (ppm) }\end{array}$} & \multicolumn{4}{|c|}{ Sultan } & \multicolumn{4}{|c|}{ Glorious } \\
\hline & & \multicolumn{2}{|c|}{$\begin{array}{c}\text { Disease } \\
\text { severity } \%\end{array}$} & \multicolumn{2}{|c|}{$\begin{array}{c}\text { Efficiency } \\
\%\end{array}$} & \multicolumn{2}{|c|}{$\begin{array}{c}\text { Disease } \\
\text { severity \% }\end{array}$} & \multicolumn{2}{|c|}{ Efficiency \% } \\
\hline & & Before & After & Before & After & Before & After & Before & After \\
\hline M. azec & 5000 & 15.5 & 22. & 71.1 & 57.8 & 8.8 & 13.7 & 70.5 & 53.5 \\
\hline rach+Thiovit80 & $3750+625$ & 8.3 & 16.1 & 84.5 & 69.9 & 4.6 & 8.8 & 4 & 70.1 \\
\hline M. azedarach+Thiovit80 & $2500+1250$ & 5.4 & 11.9 & 89.9 & 77.5 & 2.9 & 6.2 & 90.2 & 78.9 \\
\hline M. azedarach+Thiovit80 & $1250+1875$ & 3.6 & 7.5 & 93.3 & 86.00 & 1.9 & 3.7 & 93.5 & 87.4 \\
\hline Thiovit80 & 2.5gliter(2500ppm) & 2.8 & 5.3 & 94.7 & 90.1 & 0.9 & 2.6 & 95.6 & 91.2 \\
\hline Control & & 53.6 & 53.6 & 0.0 & 0.00 & 29.5 & 29.5 & 0.0 & 0.0 \\
\hline $\begin{array}{l}\text { L.S.D. } 0.05: \\
2 \text { cv. means at e } \\
2 \text { con. means at }\end{array}$ & $\begin{array}{l}\text { of conf. } x \mathrm{Tr} \text {. } \\
\text { h of } \mathrm{cV} \times \mathrm{Tr} \text {. }\end{array}$ & \multicolumn{2}{|c|}{2.97} & & \multicolumn{2}{|c|}{$\begin{array}{l}2.1 \\
1.98\end{array}$} & \multicolumn{2}{|c|}{$\begin{array}{l}3.1 \\
2.9\end{array}$} \\
\hline
\end{tabular}


Efficiency of the three combinations as mentioned before were 84.5, 89.9 and $93.3 \%$ before inoculation, while fungicide (Thiovit 80 ) efficiency was $94.7 \%$. On the other hand, the efficiency of the three combination after inoculation were $69.9,77.5$ and $86.0 \%$, while the fungicide efficiency recorded $90.1 \%$ for Sultan cv.

The same trend was obtained for Glorious cv., where the efficiency for the three combination before inoculation were; 84.4, 90.2 and $93.5 \%$ in comparison with fungicide which gave $95.6 \%$. On the other side, the data show that the efficiency after inoculation for the three combination were; 70.1, 78.9 and $87.4 \%$ while for Thiovit 80 it was $91.2 \%$. Induced resistance could be achieved by applying of plant extracts like M. azedarach (Schmitt, 2006).

We selected the dose of $3 / 4 \mathrm{M}$. azedarach $+1 / 4$ Thiovit 80 , although the other combinations $1 / 4 M$. azedarach $+3 / 4$ Thiovit $80,1 / 2 M$. azedarach $+1 / 2$ Thiovit 80 and Thiovit 80 alone, have a high efficiency than $3 / 4 \mathrm{M}$. azedarach $+1 / 4$ Thiovit 80 . So, we selected the first combination to minimize both pollution and costs as well as their residual effect on the chemical fungicide on sugar.

\section{b. Field experiments:}

The effect of $M$. azedarach at concentration of $5000 \mathrm{ppm}$ and $3 / 4 \mathrm{M}$. azedarach $+1 / 4$ Thiovit 80 on the disease incidence of powdery mildew disease using Sultan and Glorious sugar beet cvs. was studied under field conditions during 2006/2007 and 2007/2008 growing season. Thiovit 80 at concentration of $2.5 \mathrm{gm} / \mathrm{liter}$ and untreated plants were used for comparison (control). Data presented in Tables 4, 5, 6 and 7 show that plant extract, or Thiovit 80 and the combination significantly reduced disease severity of $E$. polygon compared with untreated plants. However, the combination between plant extract and fungicide came the best in this respect for both Sultan and Glorious cvs. It is obvious that the efficiency of plant extract alone exceeded $50 \%$, while the efficiency of the combination was more effective in reducing disease severity of powdery mildew. It is clear from the results obtained that treated sugar beet plants with Thiovit 80 or plant extract (M. azedarach) and the combination between $3 / 4 \mathrm{M}$. azedarach $+1 / 4$ Thiovit 80 tested significantly increased sucrose, purity, TSS content and root weight of the two sugar bet cvs.; Sultan and Glorious.

Table 4 show that increase (\%) in root weight of each treatment ranged from 29.1 to $65.4 \%$ for Sultan $\mathrm{cv}$. and from 53.1 to $61.2 \%$ for Glorious cr.

On the other hand, increase (\%) in sucrose ranged between 51.5 to $67.7 \%$ for Sultan cv. while it ranged between 30.3 to $41.4 \%$ for Glorious cv. during 2006/2007 season.

During 2007/2008 season, root yield increase ranged from 40.5 to $58.8 \%$ for Sultan cv., while it ranged from 19.5 to $32.8 \%$ for Glorious cv. (Table 6).

Sucrose increase percentage ranged from 31.7 to $45.4 \%$ for Sultan cv., while it ranged from 17.8 to $28.1 \%$ for Glorious cv. (Table 6 ).

The data obtained for increase (\%) either in sucrose or root weight was confirmed by Wolf and Verreet (2002). Chlorophyll content of leaves 
(Tables 4 and 6) affected by disease severity (\%) and decreased by increasing of disease severity (\%), as mentioned by Gordon and Duniway (1981), when sugar beet leaves infected by powdery mildew show reduction of net photosynthesis as long as disease developing in comparison with healthy plants.

Table (4): Effect of plant extract (alone or mixed with a fungicide) on powdery mildew disease and certain parameters of two sugar beet cvs. under field conditions during 2006/2007 season.

\begin{tabular}{|c|c|c|c|c|c|c|c|c|c|}
\hline \multirow[t]{2}{*}{ Cultivar } & \multirow[t]{2}{*}{ Treatments } & \multirow{2}{*}{\begin{tabular}{|c|} 
Disease \\
severity \\
$(\%)$ \\
\end{tabular}} & \multirow{2}{*}{$\begin{array}{c}\text { Chlorophyll } \\
\text { content } \\
\text { (mg/gm) }\end{array}$} & \multirow{2}{*}{$\begin{array}{c}\begin{array}{c}\text { Root } \\
\text { weight } \\
\text { (kg/plant) }\end{array} \\
\end{array}$} & \multirow{2}{*}{$\begin{array}{l}\text { TSS } \\
(\%)\end{array}$} & \multirow{2}{*}{$\begin{array}{c}\text { Sucrose } \\
(\%)\end{array}$} & \multirow{2}{*}{$\begin{array}{c}\text { Purity } \\
(\%)\end{array}$} & \multicolumn{2}{|c|}{ Increase (\%) } \\
\hline & & & & & & & & $\begin{array}{c}\text { Root } \\
\text { weight }\end{array}$ & Sucrose \\
\hline \multirow{4}{*}{ Sultan } & M.az.(5000 pm) & 20.2 & 52.3 & 0.910 & 17.9 & 13.4 & 74.8 & 29.1 & 51.5 \\
\hline & M.az.+Thiovit80* & 14.8 & 67.5 & 1.659 & 21.1 & 17.4 & 82.5 & 61.1 & 62.6 \\
\hline & Thiovit80 $(2.5 \mathrm{~g} / \mathrm{L})$ & 8.5 & 74.1 & 1.866 & 24.0 & 20.1 & 83.7 & 65.4 & 67.7 \\
\hline & Control & 46.5 & 29.8 & 0.645 & 11.3 & 6.5 & 57.5 & 0 & 0 \\
\hline \multirow[t]{4}{*}{ Glorious } & M.az.(5000ppm) & 10.8 & 70.3 & 1.731 & 225 & 18.1 & 80.4 & 53.1 & 30.4 \\
\hline & M.az.t & 7.2 & 77 & 1.970 & 24.5 & 20 & 82.4 & 58.8 & 37.6 \\
\hline & Thiovit80 $(2.5 \mathrm{~g} / \mathrm{L})$ & 4.2 & 80 & 2.100 & 26.3 & 21.5 & 81.7 & 61.2 & 41.4 \\
\hline & Control & 26.9 & 54.3 & 0.811 & 17.1 & 12.6 & 73.7 & 0 & 0 \\
\hline \multicolumn{2}{|c|}{$\begin{array}{c}2 \mathrm{cv} . \text { means at each } \\
\text { treatment }\end{array}$} & 2.1 & 2.3 & 0.46 & 1.46 & 1.87 & 2.6 & 2.10 & 1.9 \\
\hline
\end{tabular}

* M. azedarach + Thiovit $=3750+625 \mathrm{pm}(\mathrm{mg} / \mathrm{L})$

Table (5): Effect of different treatments on disease severity (\%), phenols, and AUDPC of two sugar beet cvs. under field conditions during 2006/2007 season.

\begin{tabular}{|c|c|c|c|c|c|c|c|c|c|c|c|c|}
\hline \multirow{3}{*}{ Treatments } & \multicolumn{6}{|c|}{ Sultan } & \multicolumn{6}{|c|}{ Glorious } \\
\hline & \multirow{2}{*}{\multicolumn{2}{|c|}{\begin{tabular}{|c|c|} 
Disease & Efficie- \\
severity & ncy \\
$(\%)$ & $(\%)$ \\
\end{tabular}}} & \multicolumn{3}{|c|}{ Phenols } & \multirow[b]{2}{*}{ AUDPC } & \multirow{2}{*}{\begin{tabular}{|c|} 
Disease \\
severity \\
$(\%)$
\end{tabular}} & \multirow{2}{*}{\begin{tabular}{|c|} 
Efficie- \\
ncy \\
$(\%)$ \\
\end{tabular}} & \multicolumn{3}{|c|}{ Phenols } & \multirow[b]{2}{*}{ AUDPC } \\
\hline & & & Free & $\begin{array}{l}\text { Conju- } \\
\text { gated }\end{array}$ & Total & & & & Free & $\begin{array}{l}\text { Conj- } \\
\text { ugated }\end{array}$ & Total & \\
\hline \begin{tabular}{|l|} 
M.az. 5000 \\
M.az.+ \\
Thiovit $80^{\star}$ \\
Thiovit 80
\end{tabular} & $\begin{array}{l}20.2 \\
14.8 \\
8.5\end{array}$ & $\begin{array}{l}56.5 \\
68.1 \\
81.7\end{array}$ & $\begin{array}{l}20.4 \\
27.6 \\
32.4\end{array}$ & \begin{tabular}{|c|}
59.3 \\
80.2 \\
120.6
\end{tabular} & $\begin{array}{l}79.7 \\
107.8 \\
153.0\end{array}$ & $\begin{array}{c}1811.31 \\
1438.5 \\
934.75\end{array}$ & $\begin{array}{l}10.8 \\
7.2 \\
4.2\end{array}$ & $\begin{array}{l}59.8 \\
73.2 \\
84.3\end{array}$ & $\begin{array}{l}28.6 \\
32.8 \\
51.9\end{array} \mid$ & \begin{tabular}{|c|}
74.5 \\
99.3 \\
125.4
\end{tabular} & $\begin{array}{l}103.1 \\
132.1 \\
177.3\end{array}$ & $\begin{array}{c}915.82 \\
729.75 \\
366.0\end{array}$ \\
\hline Control & 46.5 & 0 & 11.9 & 51.5 & 63.4 & 4128.75 & 26.9 & 0 & 17.8 & 62.2 & 80.0 & 1934.25 \\
\hline $\begin{array}{l}\text { L.S.D. } 0.05 \\
2 \text { treatment } \\
\text { means at } \\
\text { each cv. }\end{array}$ & 2.8 & 2.1 & 1.9 & 1.8 & 4.3 & 10.1 & 2.9 & 1.9 & 2.2 & 2.7 & 3.1 & 5.60 \\
\hline
\end{tabular}

* M. azedarach + Thiovit $80=3750+625 \mathrm{ppm}(\mathrm{mg} / \mathrm{L})$

Regarding phenolic compounds; free, conjugated and total, it decreased by increasing disease severity (\%) as shown from Tables (5 and 7 ), this due to the presence of some enzymes related to the oxidation of phenol compounds. Based on the results of the experiments, we may assert that there is a negative correlation between the resistance of sugar beet varieties to powdery mildew and phenolic activity, these results in accordance with those obtained by Mayer (1987).

Table (6): Effect of plant extract (alone or mixed with a fungicide) on powdery mildew disease and certain parameters of two 
sugar beet cvs. under field conditions during 2007/2008 season.

\begin{tabular}{|c|c|c|c|c|c|c|c|c|c|}
\hline \multirow[t]{2}{*}{ Cultivar } & \multirow[t]{2}{*}{ Treatments } & \multirow{2}{*}{$\begin{array}{c}\text { Disease } \\
\text { severity } \\
(\%)\end{array}$} & \multirow{2}{*}{$\begin{array}{c}\text { Chlorophyll } \\
\text { content } \\
\text { (mg/gm) }\end{array}$} & \multirow{2}{*}{$\begin{array}{c}\text { Root } \\
\text { weight } \\
\text { (kg/plant) }\end{array}$} & \multirow{2}{*}{$\begin{array}{l}\text { TSS } \\
\text { (\%) }\end{array}$} & \multirow{2}{*}{\multicolumn{2}{|c|}{\begin{tabular}{c|c} 
Sucrose & Purity \\
$(\%)$ & $(\%)$
\end{tabular}}} & \multicolumn{2}{|c|}{ Increase (\%) } \\
\hline & & & & & & & & \begin{tabular}{|c|}
$\begin{array}{c}\text { Root } \\
\text { weight }\end{array}$ \\
\end{tabular} & ose \\
\hline \multirow{4}{*}{ Sultan } & 00ppm) & 18.4 & 60.1 & 1.315 & 20.8 & 16.7 & 80.2 & 40.5 & 31.7 \\
\hline & M.az.+Thiovit80* & 12.8 & 71.5 & 1.730 & 23.6 & 19.5 & 82.6 & 54.7 & 41.5 \\
\hline & Thiovit80 $(2.5 \mathrm{~g} / \mathrm{L})$ & 7.5 & 82.3 & 1.887 & 25.3 & 20.9 & 82.6 & 58.8 & 45.4 \\
\hline & Control & 37.6 & 47.6 & 0.782 & 15.5 & 11.4 & 73.5 & 0 & 0 \\
\hline \multirow{4}{*}{ Glorious } & M.az.(5000 pm) & 10.9 & 75.4 & 1.845 & 24.2 & 19.6 & 80.9 & 19.5 & 17.8 \\
\hline & M.az.+Thiovit $0^{*}$ & 7.4 & 81.8 & 1.857 & 24.6 & 20.0 & 81.3 & 20.0 & 19.5 \\
\hline & Thiovit80 $(2.5 \mathrm{~g} / \mathrm{L})$ & 3.2 & 89.2 & 2.210 & 26.1 & 22.4 & 85.8 & 32.8 & 28.1 \\
\hline & Control & 18.7 & 62.5 & 1.485 & 20.5 & 16.1 & 78.5 & 0 & 0 \\
\hline \multicolumn{2}{|c|}{$\begin{array}{c}\text { L.S.D. 0.05: } \\
2 \text { cv. means at each } \\
\text { treatment }\end{array}$} & 1.9 & 2.4 & 0.39 & 1.21 & 1.96 & 1.12 & 3.1 & 2.1 \\
\hline
\end{tabular}

* M. azedarach + Thiovit $=3750+625 \mathrm{ppm}(\mathrm{mg} / \mathrm{L})$

Regarding AUDPC as shown from Table 5 and 7, the data show that under natural infection the area recorded the highest, while it recorded the lowest when the plants were treated by Thiovit 80 . When disease severity increased, AUDPC increased. On the other side, AUDPC of Glorious cv. were low comparing with Sultan, due to the level of resistance for both cvs.

Table (7): Effect of different treatments on disease severity (\%), phenols, and AUDPC of two sugar beet cvs. under field conditions during 2007/2008 season.

\begin{tabular}{|c|c|c|c|c|c|c|c|c|c|c|c|c|}
\hline \multirow{3}{*}{ Treatments } & \multicolumn{6}{|c|}{ Sultan } & \multicolumn{6}{|c|}{ Glorious } \\
\hline & \multicolumn{2}{|c|}{ Disease Efficie- } & \multicolumn{3}{|c|}{ Phenols } & \multirow[b]{2}{*}{ AUDPC } & \multicolumn{2}{|c|}{ Disease Efficie- } & \multicolumn{3}{|c|}{ Phenols } & \multirow[b]{2}{*}{ AUDPC } \\
\hline & $\begin{array}{c}\text { severity } \\
(\%)\end{array}$ & $\begin{array}{l}\text { ncy } \\
(\%)\end{array}$ & Free & $\begin{array}{l}\text { Conju- } \\
\text { gated }\end{array}$ & Total & & $\begin{array}{c}\text { severity } \\
(\%)\end{array}$ & $\begin{array}{l}\text { ncy } \\
(\%)\end{array}$ & Free & $\begin{array}{l}\text { Conju- } \\
\text { gated }\end{array}$ & Total & \\
\hline $\begin{array}{l}\text { M.az. } 5000 \\
\text { M. az. } \\
\text { Thiovit } 80^{*} \\
\text { Thiovit } 80\end{array}$ & $\begin{array}{c}18.4 \\
12.8 \\
7.5\end{array}$ & $\begin{array}{l}51.1 \\
65.9 \\
80.1\end{array}$ & \begin{tabular}{|l|}
24.8 \\
34.5 \\
40.3
\end{tabular} & $\begin{array}{l}61.5 \\
68.9 \\
84.7\end{array}$ & $\begin{array}{c}86.3 \\
103.4 \\
125.0\end{array}$ & $\begin{array}{l}1381.5 \\
1285.5 \\
768.75\end{array}$ & $\begin{array}{l}9.2 \\
6.1 \\
3.2\end{array}$ & $\begin{array}{l}54.9 \\
70.1 \\
84.3\end{array}$ & $\begin{array}{l}30.8 \\
30.1 \\
54.3\end{array}$ & $\begin{array}{c}76.3 \\
110.8 \\
131.5\end{array}$ & $\begin{array}{l}107.1 \\
140.9 \\
185.8\end{array}$ & \begin{tabular}{|l|l|}
998.23 \\
924.25 \\
3 \\
285.75
\end{tabular} \\
\hline Control & 37.6 & 0 & 14.6 & 54.4 & 69.0 & 3298.5 & 20.4 & 0 & 21.5 & 65.2 & 86.7 & 1795.41 \\
\hline $\begin{array}{c}\text { L.S.D. } 0.05 \\
2 \text { treatment } \\
\text { means at } \\
\text { each cv. }\end{array}$ & 3.1 & 2.6 & 2.9 & 2.3 & 5.1 & 9.2 & 1.5 & 3.0 & 2.7 & 3.2 & 4.6 & 6.7 \\
\hline
\end{tabular}

M. azedarach + Thiovit 80=3750 + 625 ppm (mg/L)

It could be concluded that the selected combination gave satisfactory control to powdery mildew disease and could be recommended especially for developing countries, where chemical control would be economically cropping especially if repeated spraying is done. Similar results were reported elsewhere using extracts other than those reported herein i.e. Mori et al. (1989) and Chaturvedi et al. (1987). The present result would be of a great importance since it would minimize the costs of control process, save the exploited quantity of fungicide and finally will reduce environmental pollution and increase the gross sugar yield, as well as eliminate the fungicidal residual effect in processed sugar. 


\section{REFERENCES}

Al-Abed, A.S. (1992). Possible antifungal effects of aqueous extracts and residues of some common wild plant species on certain plant. M.Sc. Thesis, University of Jordan. p. 81.

A.O.AC., Association of Official Analytical Chemicals (1990). Official Methods Analysis of the Association of Official Analytical Chemicals. Washington, 25 D.C. USA.

Ashry, M.A.; Sh. El-El-Hamdy; E.A. Salem; M.A. Abdel-Baki, M.R. Sehly; Z.H. Osman and M.A. Abbasy (1999). In vitro and In vivo effects of certain plant extracts on rice blast disease caused by Pyricularia oryzae Cav. J. Agric. Res. Tanta Univ., 25(2), 1999.

Bray, H.G. and W.V. Thrope (1954). Analysis of phenolic compounds of interest in metabolism methods of chemical analysis, 27-51.

Chaturvedi, R.; A. Dikshit and S.N. Dixit (1987). Adenocalymma ollicea, a new source of natural fungitoxicant. Trop. Agric. 64: 318-22.

El-Fahar, Samia, A. (2003). Integrated management of Cercospora leaf spot disease of sugar beet in Delta area. Ph.D. Thesis, Fac. of Agric., Kafr El-Sheikh, Tanta Univ.

El-Fahar, Samia, A. (2008). Impact of powdery mildew disease on root weight, sugar yield and purity of sugar beet. J. Agric. Res. Kafr ElSheikh Univ., 34(3): 2008.

Gomez, K. and A.C. Gomez (1983). Statistical Procedures for Agricultural Research, International Rice Research Institute, Book. John Wiley and Sons, New York, pp. 403.

Gordon Thomes, R. and John M. Duniway (1981). Effects of powdery mildew infection on the efficiency of $\mathrm{CO}_{2}$ fixation and light utilization by sugar beet leaves. Plant Physiol. 1982, 69, 139-142.

Gouda, M.I. (2001). Studies on some causes of sugar beet root rots. Ph.D. Thesis, Fac. of Agric. Tanta Univ. Egypt. p. 146.

Grimmer, M.K.; K.M.R. Bean and M.J.C. Asher (2007). Mapping of five resistance genes to sugar beet powdery mildew using AFLP and anchored SNP markers. Theoretical and Applied Genetics, 115(1), pp. 67-75.

Hills, F.J.; L. Chirappa and S. Geng (1980). Powdery mildew on sugar beet. Disease and crop Assessment. Phytophathology. Vol. 70, No. 7.

Karaoglanidis, G.S. and D.A. Karadimos (2005). Efficacy of strobilurins and mixtures with DMI fungicides in controlling powdery mildew in fieldgrown sugar beet. Crop Protection. 25(2005): 977-983.

Kishore, N.; N.K. Dubey; R.D. Tripathi and S.K. Singh (1982). Fungitoxic activity of leaves of some higher plants. National Academy Science Letter, 5(1): 9-10.

Mayer, M.A. (1987). Polyphenoloxidases in plants recent progress. Phytochemistry, 26(1): 11-20.

McGinnis, R.A. (1982). Beet sugar technology. $3^{\text {rd }}$ edn. Beet sugar development foundation fort Collins. 855 pp. 
Mori, A.; N. Enaki; K. Shinozuka; C. Nishino and M. Fukushima (1987). Antifungal activity of fatty acids against Pyrcularia oryzae related to antifungal constitutions of Miscanthus sinensis. Agric. Biol., Chem. 51: 3403-05.

Pandy, H.N.; T.C. Menon and Rao (1989). A simple formula for calculating area under disease progress curve. Rachis, 8(2): 38-39.

Paulus, A.O. (2008). Sugar beet post management : leaf diseases. U. Bulletin No. 3278. ANR Publications. Oakland, CA 94608-1239.

Prakash, A. and J. Rao (1997). Botanical pesticides in Agriculture. Lewis Publishers, CRC, Press.

Schmitt, A. (2006). Induced resistance with extracts of Reynoutria sachalinensis: Crucial steps behind the scene induced resistance in plants against insects and diseases, IOBC WPRS Bulletin. Vol. 29(8), 2006.

Scott, W.P. and G.H. McKibben (1978). Toxicity of black pepper extract to boll weevils. J. Econ. Entomol. 71(2): 343-344.

Shimon, M.; E. Putievsky; V. Ravid and R. Rcoyeni (1993). Antifungal activity of volatile fractions of essential oils from four aromatic wild plants in Israel. J. of Chem. Ecol., 19(6): 1129-1133.

Snell, F.D. and C.T. Snell (1953). Calorimetric methods of analysis including some turbidimetric and nephelometric methods. D. Van Nostrand Company Inc. Tornto. New York, London. Vol. III, 606 pp.

Wolf, P.F.J. and J.A. Verreet (2002). The IPM sugar Beet Model Plant Disease. Vol. 86 No. 4.

Yoshida, S.; D. Forno; J. Cock and K. Gomez (1976). Laboratory manual for physiological studies of rice. $3^{\text {rd }}$ ed. pp. 83. The International Rice Research Institute, Los Banos, Philippines, Manila, Philippines.

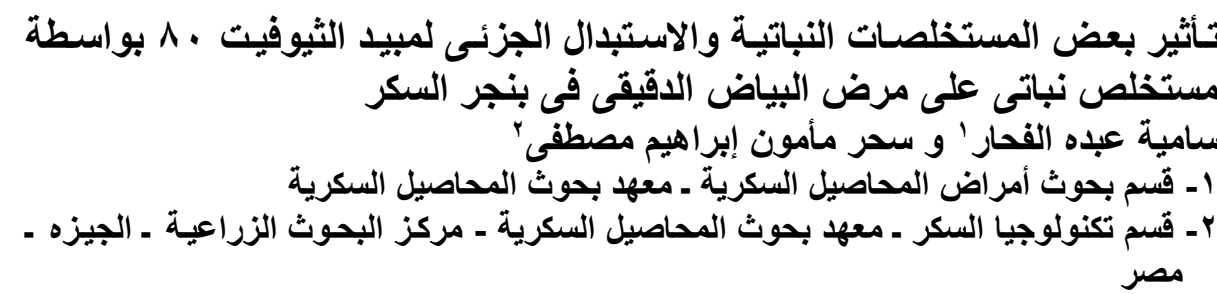

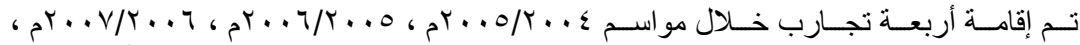

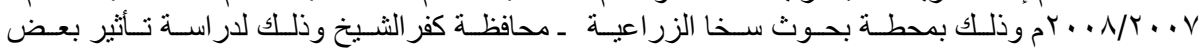

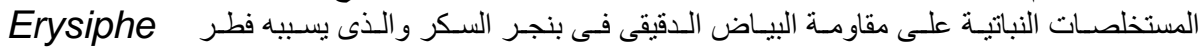
polygoni

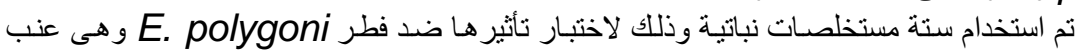

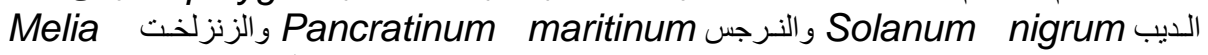

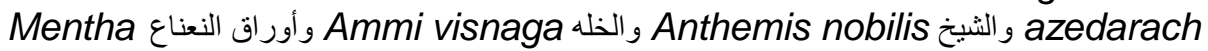

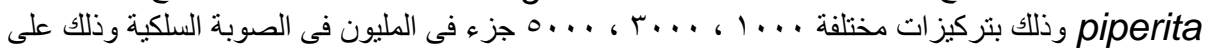

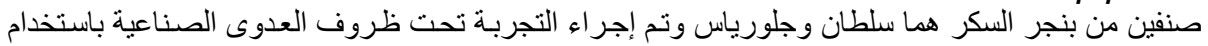
الجر اثيم الكونيدية للفطر ـ ولخفض الجرعة المستخدمة من المبيد الفطرى Thiovit 80 ضد الند الفطر تم خلط 


\section{El-Fahar, Samia A. and Sahar M.E. Moustafa}

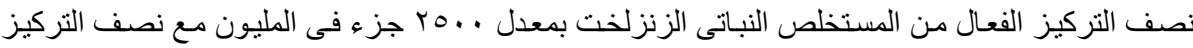

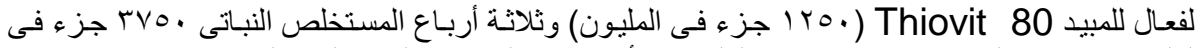

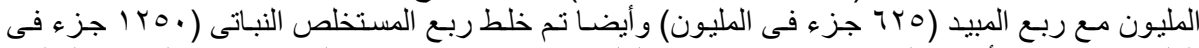

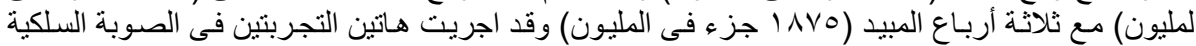

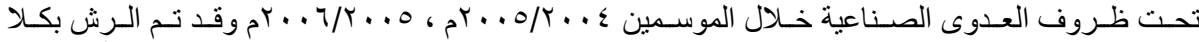

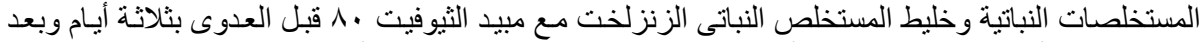

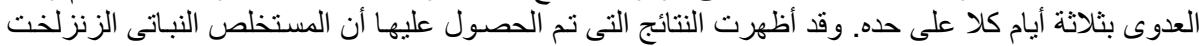

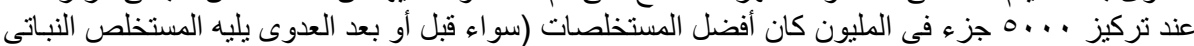

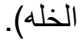

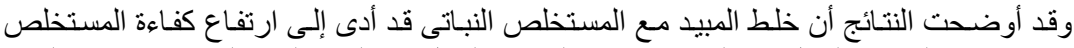

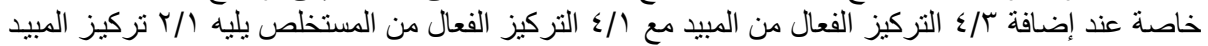

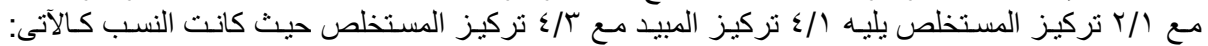

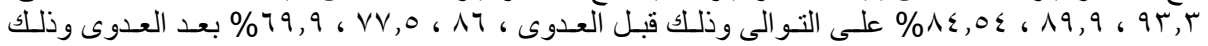

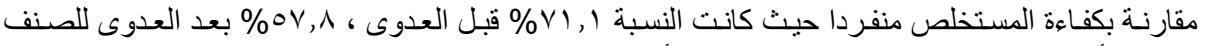

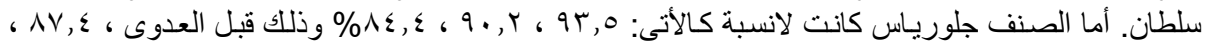

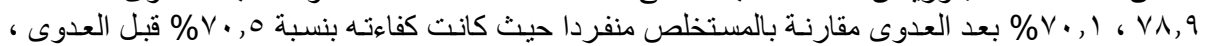

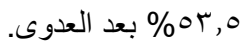

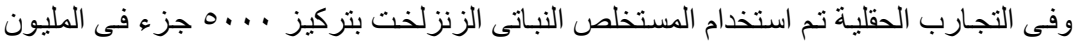

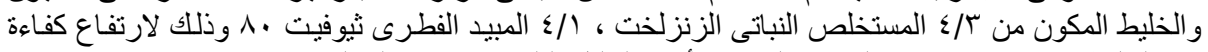

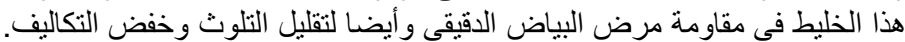

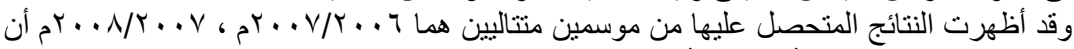

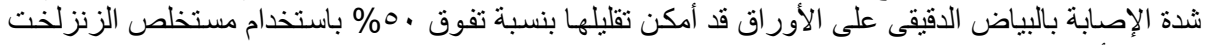

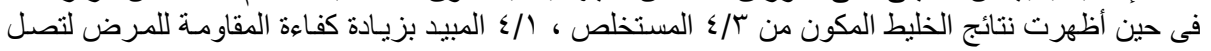

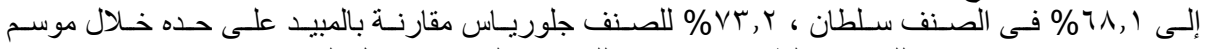

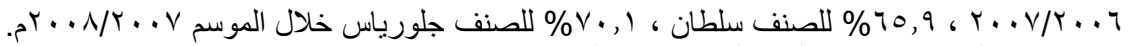

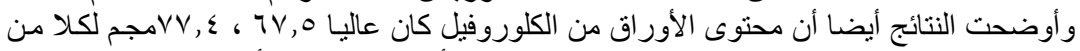

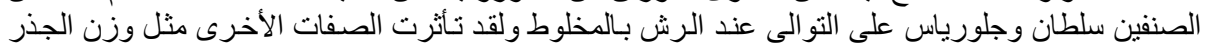

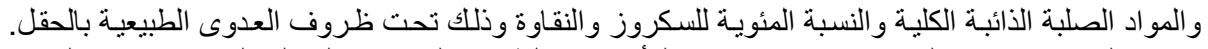

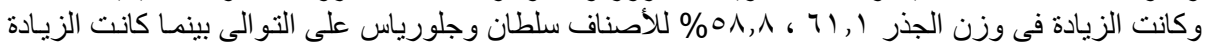

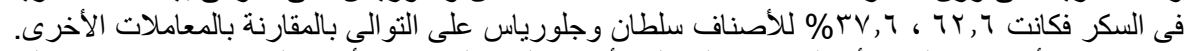

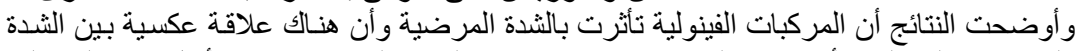

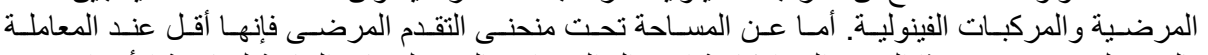

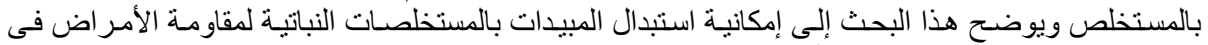

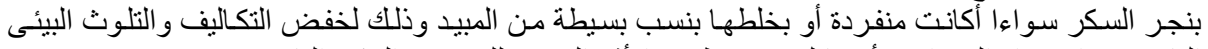
الناجم عن استخدام المبيدات و أيضا التلافى خطورة الأثر المتبقى للمبيد في السكر الناتج. 